\title{
CORPORATE PERSONALITY: UTILISING TRUST LAW TO INVOKE THE APPLICATION OF THE CONCEALMENT PRINCIPLE
}

\begin{abstract}
The landmark Supreme Court judgment in Prest v Petrodel Resources Ltd provides a significant re-assessment of the law relating to a court's ability to circumvent corporate personality. The Supreme Court considered that the application of ordinary legal principles ('the concealment principle') should ordinarily override a court's ability to apply an equitable veil-piercing doctrine ('the evasion principle'). Whilst accepting the primacy of the concealment principle, this article disputes the correctness of the Supreme Court's implied assertion that, in cases concerning 'one man-type' companies, the concealment principle should be advanced through application of agency-derived principles. Rather, this article contends that the concealment principle should be progressed by adopting solutions derived from the law of constructive trusts and associated principles of equity. To an objective of providing a doctrinally sound framework for the development of the law in the post-Prest era, this article further suggests that the constituent elements of the evasion principle could be consistent with the operation of a distinct species of constructive trust. Moreover, it is argued that, in future, this 'evasion trust' should, in complete abrogation of the equitable piercing doctrine, be developed so as to apply in all cases exhibiting intentional and fraudulent abuses of the incorporation process.
\end{abstract}

\section{INTRODUCTION}

A company incorporated in accordance with the companies legislation is regarded as a distinct legal entity which, as a legal person, possesses rights and incurs obligations in a manner akin to a natural person. ${ }^{1}$ The legal rights and obligations of both a company and its human constituents are separated by what is often referred to as the 'corporate veil'. This enduring construct of corporate law, enshrined in the decision of the House of Lords in Salomon $v$ A Salomon \& Co Ltd ${ }^{2}$ establishes that a company, having been legitimately incorporated with a limited liability status, is responsible ordinarily for its own debts and liabilities. In promoting a risk-adverse advantage for the human constituents of the limited liability company, the Salomon principle may be seen as being conducive to a commercial trading system which encourages economic growth to the ultimate benefit of the national economy.

The commercial advantage of incorporating a company may, however, be subject to abuse, particularly by the controllers of 'one-man type companies' ${ }^{3}$. The recent decision of the Supreme Court in Prest $v$ Petrodel Resources Ltd ${ }^{4}$ acknowledges that, as a matter of equity, it may be necessary to disturb corporate personality by piercing the corporate veil. The Supreme Court, in reviewing previous 'veil-piercing cases' related to 'one-man type

\footnotetext{
1 See Companies Act 2006, s 16.

2 [1897] AC 22.

3 This phrase is used in this paper in recognition that, although a 'one-man company' is one in which there is a sole beneficial shareholder, there are many companies, which, whilst not technically 'one man companies', are companies in which an individual controls a majority of the shares and dominates management without necessarily being the sole shareholder. The phrase 'one-man type company' includes the latter as well as the former.

4 [2013] UKSC 34; [2013] 2 AC 415.
} 
companies', considered, however, that the law in this area was 'unsatisfactory and confused' ${ }^{5}$ to the extent that the judicial reasoning of many of the 'veil cases' required a significant reassessment. ${ }^{6}$ This reassessment led the Supreme Court to a conclusion that, whenever possible, conventional legal principles ought, in future cases, to be utilised in preference to applying the equitable piercing doctrine. This ability to outflank the Salomon principle, without the necessity of piercing the veil, was referred to as the "concealment principle'. With the exception of Lord Walker, ${ }^{7}$ the Supreme Court nevertheless concluded that the courts do possess an inherent jurisdiction to pierce the corporate veil in circumstances when the concealment principle cannot be applied. Here, a majority ${ }^{8}$ took the view that this veil-piercing jurisdiction should ordinarily be exercised only in accordance with the 'evasion principle', that is, in a situation where a company's controller (usually the company's majority shareholder) sought to avoid a pre-existing legal obligation by purporting to hide that obligation behind the corporate veil of the company under his control (hereafter referred to as a 'device company'). ${ }^{9}$ As a consequence of the very restrictive ambit of the evasion principle, it is to be observed that a court's ability to remedy injustices arising from this strict and arbitrary application of the Salomon principle may be ultimately dependent on its ability to utilise the concealment principle.

The issues in Prest concerned a claim for ancillary relief in which the wife alleged that certain properties registered in the name of companies which the husband controlled were actually owned beneficially by the husband. It is to be observed that the husband had not caused title to the properties to be vested in the companies in any attempt to evade any existing liability. The factual circumstances of the case therefore fell outside the remit of the evasion principle. ${ }^{10}$ The Supreme Court was, however, able to apply the concealment principle, in so far as the facts of the case established that the companies held the properties on resulting trust for the husband. It should be noted that in Prest, the Court's general analysis of the concealment principle was focused on factual circumstances related to

\footnotetext{
${ }^{5}$ Above $\mathrm{n} 4$ [at 498] per Lord Neuberger.

${ }^{6}$ See especially Lord Neuberger's judgment, above $n 4$ at [498-503].

7 Lord Walker considered [at 508] that piercing the corporate veil was not a doctrine, or a coherent principle or a rule of law, but simply a label which had often been used indiscriminately to describe the disparate occasions on which some rule of law produced an apparent exception to the Salomon principle..

8 The majority view was represented by Lord Neuberger, Lord Sumption, Lord Mance and Lord Clarke. Lord Mance and Lord Clarke did not, however, wish to foreclose all possible future situations in which a court would be justified in piercing the corporate veil, albeit accepting that such situations were likely to be novel and very rare. Representing the minority view, Baroness Hale (above $n 4$ [at 506]) with whom Lord Wilson agreed, opined that the cases in which the corporate veil had been pierced should be viewed more simply as examples of a much broader principle which prohibited individuals who operated limited companies from taking unconscionable advantage of the people with whom they did business.

9 This novel classification of the 'piercing cases', split between either the evasion principle or the concealment principle, was advanced by Lord Sumption, above $\mathrm{n} 4$ [at 484]. Lord Sumption's classification has been accepted in several subsequent authorities- eg $R v$ Boyle Transport (Northern Ireland) Ltd [2016] EWCA Crim 19; [2016] 4 WLR 63; R v McDowell [2015] EWCA Crim 173; [2015] 2 Cr App R (S) 14; Airbus Operations Ltd v Withey [2014] EWHC 1126 (QB); R v Sale [2013] EWCA Crim 1306; [2014] 1 WLR 663.

10 The properties had been purchased by the husband in the names of the companies, or transferred by him to the companies. The husband had not sought to evade any existing liabilities when the transfers occurred. He had, however, failed to comply with court orders relating to evidence about the transfer of the properties and had deliberately concealed relevant facts and details about the transfer. The Supreme Court held therefore that there was no evidence to rebut a presumption that the company took the properties as a resulting trustee for the husband who was to be regarded as the beneficial owner of the same. Accordingly, the properties formed a part of the matrimonial assets.
} 
commercial law matters, although it should be observed that the concealment principle may also be advanced to circumvent corporate personality in other areas of law. ${ }^{11}$

Significantly, a majority of the Court considered that previously decided commercial law 'piercing-type cases' could also have been more appropriately decided by applying the concealment principle. ${ }^{12}$ In relation to the 'piercing-type cases' considered by the Supreme Court, the analysis of the concealment principle favoured the application of legal principles deriving from agency law, although, in places, the Court drew little distinction between the law of trusts and the law of agency. For instance, Lord Sumption referred to a device company taking as 'agent or nominee'13 or 'nominee or trustee'14 of its controller, and Lord Neuberger referred to the resolution of cases 'based on agency or trusteeship'. ${ }^{15}$ This apparent merger of legal principles took place notwithstanding that trusts and agency arrangements comprise very different legal mechanisms. ${ }^{16}$ This is not, however, the first instance of this peculiar lack of precision. Indeed, in Salomon, Lord Watson lamented:

...[w]hat is meant by the assertion that the company 'was the mere nominee or agent' of the appellant I cannot gather from the record; and I am not sure that I understand precisely in what sense it was interpreted by the learned judges whose decisions we have to consider. ${ }^{17}$

In Prest, the Supreme Court's analysis of the concealment principle was influenced significantly by the application of agency law principles and was, in effect, absent of any significant discussion of trust law principles. This article will contend, however, that in the advancement of the concealment principle, the Court, in the alternative, should have concentrated its attention on relevant legal principles applicable to the law of trusts. In the provision of a doctrinally sound framework to support the development of the concealment principle in the post-Prest era, a primary purpose of this article will be to establish that, in the correct explanation of 'piercing cases' involving 'one-man type companies', the application of ordinary rules relating to trust law advances greater clarity and certainty than the rules of agency law. Further, to an objective of removing any confusion and uncertainty in the application of the law in matters relating to the courts ability to disturb the corporate veil in commercial law matters, the article will seek to establish that both the concealment and evasion principles may be properly rationalised and explained by the deployment of trust law principles.

The first part of the article will analyse the judgments in Prest in relation to the Supreme Court's categorisation of both evasion and concealment cases. The second part of the article will consider initially the striking problematical issues in the use of agency law principles to support the concealment principle in the context of 'one man-type companies'. Thereafter, this part will illustrate how trust law may be applied to explain and further advance an acceptance of the concealment principle in the more frequently encountered

11 For example, in Chandler v Cape plc [2012] 1 WLR 3111, the application of principles of tort enabled the corporate veil to be circumvented. Furthermore, in McDowell, above $\mathrm{n}$ 9, the concealment principle was invoked so that a device company's receipt of the proceeds of a crime could be regarded as its controller's receipt for the purposes of applying the Proceeds of Crime Act 2002.

12 The minority view was expressed by Baroness Hale above $\mathrm{n} 4$ [at 506], with whom Lord Wilson agreed. Both doubted that the cases should be classified into either concealment or evasion cases.

${ }^{13}$ Above $n 4$ [at 487].

${ }^{14}$ Above $n 4$ [at 479].

${ }^{15}$ Above $\mathrm{n} 4$ [at 503].

${ }^{16}$ It is possible for an agent to assume the responsibilities of a trustee, but the authorities provide a stringent test to justify this finding. This test is unlikely to be satisfied in cases that are concerned with veil-piercing. See Pearson v Lehman Brothers Finance SA [2010] EWHC 2914 (Ch).

17 Above $\mathrm{n} 2$. 
'piercing-type cases' namely, those of a kind involving a fiduciary and their device company being deemed jointly and severally liable for permitting the 'fruits' of a breach of fiduciary duty to be exploited by the device company. The final part of the article will consider how trust law principles may also be applied to explain cases which incorporate the constituent elements of the evasion principle and will also explore the potential to extend the application of such principles to other 'piercing-type cases' exhibiting a fraudulent abuse of the incorporation process but which, on their facts, fall outside of the strict requirements of the evasion principle.

\section{CLASSIFYING EVASION AND CONCEALMENT CASES}

In Prest, both Lord Sumption and Lord Neuberger delivered substantive obiter judgments relating to the classification of existing 'piercing-type cases.' This discussion, however, identified only four 'piercing-type cases' 18 which their Lordships divided into 'evasion' or 'concealment' categories. An evasion case was defined by Lord Sumption ${ }^{19}$ as one in which:

a person is under an existing legal obligation or liability or subject to an existing legal restriction which he deliberately evades or whose enforcement he deliberately frustrates by interposing a company under his control.' ${ }^{20}$

In contrast, his Lordship defined a concealment case defined as one:

involving the application of conventional legal principles, the effect of which would override an arrangement in which a company $(A)$ had been interposed for the benefit of another person (B) to the purpose of disguising the true nature of that arrangement. $^{21}$

The primary motivation behind the conception of the evasion and concealment principles related to a judicial concern at the lack of clarity in the law. In VTB Capital plc v Nutritek International Corp. ${ }^{22}$ for example, Lord Neuberger observed that:

the 'nature, basis and meaning of the [piercing] principle are all somewhat obscure', and that the use of metaphorical expressions 'such as "the true facts", "sham", "mask", "cloak", "device", or "puppet"... are often dangerous, as they risk assisting moral indignation to triumph over legal principle, and, while they may enable the court to arrive at a result which seems fair in the case in question, they can also risk causing confusion and uncertainty in the law'. ${ }^{23}$

In Prest the same judge emphasised the 'importance of maintaining clarity and simplicity in this area of law' 24 as did Lord Sumption, who decried the 'confusion in concepts' 25 and

18 Gilford Motor Co v Horne [1933] Ch 935; Jones v Lipman [1962] 1 WLR 832; Trustor AB v Smallbone (No 2) [2001] 1 WLR 1177; Gencor ACP Ltd v Dalby [2000] 2 BCLC 734.

19 Lord Neuberger agreed with this definition, above $n 4$ at [at 499].

20 Above $\mathrm{n} 4$ [at 487].

${ }^{21}$ Above $\mathrm{n} 4$ [at 498].

22 [2013] UKSC 5; [2013] 2 A.C. 337.

23 Ibid [at 383].

${ }^{24}$ Above $\mathrm{n} 4$ [at 67 ].

${ }^{25}$ Above $n 4$ [at 32]. 
'incautious dicta and inadequate reasoning' ${ }^{26}$ inherent in some existing veil-piercing authorities. $^{27}$

Accordingly, it is jurisprudentially desirable and within the spirit and intendment of Prest to suggest that if the concealment principle is to advance the future development of 'piercing-type cases', then such an advancement must be-effected through a medium of law that is doctrinally clear. This medium should, for example, promote predictability and certainty in the law, although it should not encourage a multiplicity of claims to undermine the Salomon principle.

In Prest, Lord Sumption considered that the evasion principle, although lacking any general doctrinal justification, was well established in English law. ${ }^{28}$ His Lordship conceded, however, that the cases in which the evasion principle had hitherto been applied could have been better explained in full, or in part, as concealment cases. ${ }^{29}$ For his part, Lord Neuberger considered that the four 'piercing cases' discussed in the Prest judgment could and should have been resolved without recourse to the evasion principle, albeit his Lordship, accepted (with some reluctance), that the evasion principle should be retained as a limited form of judicial tool, one which should be used sparingly as a last resort to the objective of undoing a wrongdoing in a situation where no other legal principle (the concealment principle) could be applied. ${ }^{30}$

The first and pivotal 'piercing case' to be discussed by their Lordships was the decision of the Court of Appeal in Gilford Motor Co v Horne. ${ }^{31}$ Here, a Mr Horne caused a company under his control ${ }^{32}$ to solicit the claimant's customers in a fraudulent attempt to evade a covenant which provided that he should not solicit the customers. The court invoked an equitable veil-piercing principle, derived from the pre-Salomon case of Smith v. Hancock, ${ }^{33}$ to justify issuing an injunction against both Horne and the device company to restrain future breaches of the covenant. The equitable principle enunciated in Smith was to the effect that where a valid legal obligation (in Smith, a restrictive covenant) prevented the vendor of a business from setting up a competing business, the obligation should also be deemed valid in circumstances that were considered necessary to prevent the vendor retaining an interest in any competing unincorporated business which was in the 'sham' ownership of his wife or a close relative or associate. In Gilford, the Court of Appeal applied this principle within a corporate context, and Horne's device company was viewed as a 'sham', acting as if it was an agent of its controller. ${ }^{34}$ While the Court of Appeal adopted a

\footnotetext{
${ }^{26}$ Above $\mathrm{n} 4$ [at 19]. Similar concerns over clarity and/or injudicious invocation of principle were expressed by Lord Clarke [at 103] and Lord Wilson [at 106].

27 Interestingly, Harding has recently argued that a 'modal conception' of the rule of law should encompass 'values like clarity, consistency and predictability in the legal system'. The similarity between the attributes identified by Harding and those alluded to by Lord Neuberger is striking, see M.Harding, 'Equity and the Rule of Law' (2016) 132 LQR 278, 280. The desirability of such values identified by Harding has been emphasised both judicially and academically many times. See, for example Merkur Island Shipping Corp. v Laughton [1983] 2 AC 570 at 612 per Lord Diplock; Lord Bingham, 'The Rule of Law' (2007) 66 CLJ 67, 70. In respect of the need for clarity in specifically in veil-piercing cases, see also the judicial and academic authorities discussed by Lord Neuberger in Prest, above n 4 [at 74-78].

${ }^{28}$ Above $n 4$ [at 484]. Lord Clarke agreed with Lord Sumption on this point [at 507].

${ }^{29}$ Above $\mathrm{n} 4$ [at 511-513].

30 Above $\mathrm{n} 4$ [at 502-503].

${ }^{31}$ Above $\mathrm{n} 18$.

32 The shares were held by nominees for Horne, and he was, at the very least, a shadow director.

33 [1894] 2 Ch 377.

${ }^{34}$ Above n 18 [at 961-962] per Lord Hanworth MR.
} 
significant agency analogy in the language of the judgment, ${ }^{35}$ its decision was one founded on a separate, albeit imprecisely defined, equitable piercing principle, taken and adapted from the judgment in Smith v. Hancock.

In Prest, Lord Neuberger contended, however, that, as the device company in Gilford was subject to Horne's absolute control, the case should have been decided solely on the basis of agency principles. As such, Lord Neuberger declined to accept Gilford as a true example of an 'evasion case'. ${ }^{36}$ Lord Sumption also considered that the injunction against Horne was better explained by way of agency principles (applying the concealment principle), although his Lordship considered that the injunction against the device company was more appropriately explained by the evasion principle. ${ }^{37}$ If, however, the concealment principle aptly described Horne's position as a principal, it would have seemed to follow that the injunction against the device company could equally have been explained by agency law principles. ${ }^{38}$ Lord Sumption advanced no explanation for the said division of the concealment and evasion principles although one possible explanation would be that his Lordship believed that a 'one-man type company' could not be liable as if it were the agent of its controller. It should be observed, however, that in the subsequent analysis of Trustor $A B v$ Smallbone (No 2) ${ }^{39}$ and Gencor ACP Ltd v Dalby ${ }^{40}$ (discussed below), Lord Sumption advanced a contradictory approach in so far as his Lordship opined that the respective device companies, (both 'one-man type companies,') should have been properly regarded as agents (emphasis added) or trustees of their respective controllers. ${ }^{41}$

On the point of whether a device company can be regarded as an agent of its controller, it is respectfully submitted that the correct legal position is to be found in the judgments of the House of Lords in Salomon. ${ }^{42}$ In Salomon, both the Court of Appeal and the House of Lords refuted the first instance decision of Vaughn Williams $\mathrm{J}$, in which the learned judge had applied agency principles to disturb the corporate personality of $A$. Salomon \& Co Ltd. For example, in the House of Lords judgment, Lord Herschell opined:

In a popular sense, a company may in every case be said to carry on business for and on behalf of its shareholders; but this certainly does not in point of law constitute the relation of principal and agent between them or render the shareholders liable to indemnify the company against the debts which it incurs. ${ }^{43}$

\footnotetext{
35 Above n 18 [at 961-962] per Lord Hanworth MR [at 956]. Also, at first instance, Farwell J, [at 937], explained that the defendant company was susceptible to the injunction because Horne was 'committing breaches of the covenant by the agency of the defendant company'. Both Lawrence LJ [at 965] and Romer LJ [at 969] expressed agreement with Farwell J on this point.

36 Above n 4 [at 500].

37 Above n 4 [at 485].

38 I.e. as an agency relationship requires both a principal and agent, if Horne was considered to be the principal in the relationship, it would ordinarily follow that the device company should be regarded as Horne's agent. As to the permissibility of granting an injunction directly against both principal and agent, see Prest, above n 4 [at 500] per Lord Neuberger.

${ }^{39}$ Above n.18.

40 lbid.

41 Above n.4 [at 487]. As Lord Sumption considered that the device companies could have been viewed to be agents of their controllers, it is difficult to determine with certainty whether his Lordship did actually hold the view that a 'one-man type company' could never be viewed as an agent of its controller.

42 Indeed, there would appear to be no binding authority to substantiate the claim that a device company, in the guise of a 'one-man type company', can act as the agent of an individual in circumstances where the basis of the alleged agency relationship is founded upon the individual exerting absolute control over the device company.

43 Above n 2 [at 43].
} 
While the judgment in Gilford was undoubtedly influenced, although not decided, by applying agency law principles, the agency analogy presented an obvious conflict with the reasoning adopted by the House of Lords in Salomon. ${ }^{44}$ The Gilford case, however, led future courts to a conclusion that, as a matter of equity, it was possible to pierce the corporate veil of a company in circumstances where the shield of the company's distinct legal status was used intentionally to hide an existing legal obligation of its controller. This equitable piercing principle was applied subsequently in Jones $v$ Lipman. ${ }^{45}$ In Jones, a Mr Lipman sought to escape specific performance of a contract for the sale of land by conveying the land to a recently acquired company (the device company). ${ }^{46}$ Russell $\mathrm{J}$ held that the device company had been interposed to evade Lipman's contractual responsibility, to a conclusion that specific performance for the sale of land was granted against both Lipman and the device company. The learned judge stated:

The defendant company is the creature of the first defendant, a device and a sham, a mask which he holds before his face in an attempt to avoid recognition by the eye of equity. ${ }^{47}$

It is to be observed that following the decision in Jones, the factual requirements necessary to the implementation of the equitable veil-piercing principle severely restricted its future application. ${ }^{48}$

In Prest, Lord Neuberger concluded that, in Jones, Russell $\mathrm{J}$ had been mistaken in piercing the corporate veil of the device company because an order for specific performance made specifically against Lipman would, in itself, have sufficed. Lord Neuberger considered that Lipman, as the controller of the company, would have been bound to do everything that was reasonably in his power to ensure that the property was conveyed and therefore would have been compelled to facilitate a conveyance of the property from the device company to the plaintiffs. ${ }^{49}$ By contrast, Lord Sumption's explanation of the Jones case resembled his Lordship's interpretation of the Gilford case, namely that the order for specific performance against Lipman was explained by the concealment principle (by the use of agency principles) and, as against the device company, the decision was justified by way of the evasion principle. ${ }^{50}$

44 The decision of the House of Lords in Salomon, above $\mathrm{n}$ 2, was not, however, considered or even cited at first instance or by the Court of Appeal in Gilford, above $\mathrm{n} 18$.

${ }^{45}$ Above $\mathrm{n} 18$.

${ }^{46}$ Lipman was the absolute or beneficial owner of all of the shares, and was a director. The other director was seemingly a puppet of Lipman.

${ }^{47}$ Above $\mathrm{n} 18$ [at 836].

48 The successful and technically correct application of the equitable piercing principle (the evasion principle) was, however, evident in Locke (Albert) (1940) v Winsford Urban DC (1973) 71 LGR 308. In other reported cases in which the equitable piercing principle was purportedly applied, the factual circumstances of the cases failed to accord with technical requirements necessary to the correct application of the principle, ie, the façade company's distinct legal status was not used to hide an existing legal obligation of its controller, see eg Gencor, above n 18; Trustor (No 2), above n 18.

${ }^{49}$ Above $\mathrm{n} 18$ [at 836]. For a case that in part followed this reasoning see Smith v Samuel Smith Old Brewery (Tadcaster) [2007] EWCA Civ 1461.

${ }^{50}$ Above $\mathrm{n} 4$ [at 486]. It is to be observed that Baroness Hale (with whom Lord Wilson agreed) took a diverse approach in respect of the interpretation of the liability outcomes in Gilford and Jones. Her Ladyship opined that the concepts of agency and of the "directing mind" (in effect attribution principles) could have been used to establish the device company's liability (above $n 4$ at 506). Baroness Hale advanced the case of Stone \& Rolls Ltd v Moore Stephens [2009] AC 1391, as an example of a case in which corporate liability had been established by attribution principles. Attribution principles are discussed below at n 129, and accompanying text. Baroness Hale justified 
The two remaining 'piercing cases' discussed in Prest were Trustor $^{51}$ and Gencor. ${ }^{52}$ The former witnessed a complex episode of litigation which, in the context of this article, may be summarised as follows. Mr. Smallbone, the managing director of the claimant company (Trustor), breached his directors' duties; by misappropriating corporate funds, he caused Trustor to pay certain sums into the bank accounts of Introcom Ltd, a device company under Smallbone's control. ${ }^{53}$ Although some of this fund was paid to Smallbone, most was retained and then dissipated by Introcom, thus precluding the possibility of a proprietary claim against the latter.

In such circumstances, the delinquent fiduciary, in addition to being susceptible to proprietary and in personam claims in respect of the assets which had passed into his hands, would ordinarily have been liable in personam to pay equitable compensation in respect of his loss-causing breach of his director's duties. Trustor was, however, registered in Sweden and, as such, Smallbone's breach of duties to Trustor was a matter to be determined by Swedish law. The payments made to Introcom had nevertheless been procured from Trustor's account in England and, as such, any liability to be attached to these payments could be determined by an English court. ${ }^{54}$ Establishing the in personam liability of Smallbone and Introcom in respect of the sums that each had received was a relatively straightforward matter. ${ }^{55}$ The controversial question concerned the extent of Smallbone's in personam liability in respect of the funds that were received and dissipated by Introcom.

In Trustor $A B$ v Smallbone (No 3), ${ }^{56}$ the Court of Appeal heard an appeal relating to the amount for which Introcom was liable. ${ }^{57}$ Significantly for the purposes of this paper, Scott VC (delivering the Court's judgment) opined that Smallbone and Introcom should be held jointly and severally liable to account in equity in respect of the payments received and dissipated by Introcom on the basis that 'Introcom, as a constructive trustee, was in breach of trust in making payments of the Trustor money to the various payees, ${ }^{58}$ and further that these breaches of trust 'were made with the knowing assistance of Mr Smallbone'. ${ }^{59}$

Trustor subsequently applied to the Chancery Division for summary judgment against Smallbone in respect of the funds which had been retained and dissipated by Introcom. In Trustor AB v Smallbone (No 2)), ${ }^{60}$ this application was granted. Morritt VC held that Introcom and Smallbone were jointly and severally liable to account to Trustor. Unlike Scott VC, however, Morritt VC reached this conclusion by applying the equitable piercing principle established in Gilford Motor Co v Horne. He held that Introcom was liable in personam for

the controller's liability on the basis 'that the individuals who operate limited companies should not be allowed to take unconscionable advantage of the people with whom they do business. Baroness Hale did not define the term 'unconscionable advantage.'

51 Above n 18.

52 lbid.

53 In Trustor AB v Smallbone (No 1) [2000] 1 All ER 811, Rimer J found that Introcom was under the control of a Liechtenstein trust called the 'Lindsay Smallbone Trust' of which Smallbone was a beneficiary and furthermore, that the directors of Introcom were nominees acting on the instructions of Smallbone. Smallbone could therefore properly be regarded as the controller of Introcom.

${ }_{54}$ Albeit that Trustor could not recover the same amount twice.

55 Summary judgment against Introcom, rendering it liable in personam in respect of the sums that it had received, was given in August 1998 by Master Bowman by way of a RSC Ord 14 judgment. Summary judgment against Smallbone in respect of the sums that he had received personally was granted by Rimer J (Unreported, 2000).

56 OT (CA (Civ Div); 09 May 2000)

57 In Rimer J's 2000 summary judgment, he had reduced the amount payable by Introcom according to Master Bowman's original order.

58 Above n 58 [at 62].

59 Above n 58 [at 97].

60 Above n 18. 
knowing receipt of the funds and that the corporate veil of Introcom could be pierced so that the knowing receipt of Introcom should be treated as the knowing receipt of Smallbone. ${ }^{61}$ In effect, Smallbone was held liable for the knowing receipt of money that he caused to be misappropriated in breach of his own fiduciary duties. ${ }^{62}$

In Gencor ACP Ltd $v$ Dalby, ${ }^{63}$ Dalby, a former director within the APC group of companies (the group was subsequently taken over by Gencor Industries Ltd), breached his fiduciary duties by exploiting business opportunities and causing the profits to be paid directly to Burnstead Ltd, a company under his control. ${ }^{64}$ Dalby also arranged for secret commissions to be paid directly to Burnstead Ltd. ${ }^{65}$ In judgment, Rimer J held that Burnstead Ltd and Dalby were jointly and severally liable to account for the profits made by Burnstead Ltd. In establishing Dalby's liability, the learned judge concluded that '[i]f the arrival at this result requires a lifting of Burnstead's corporate veil, then I regard this as an appropriate case in which to do so.' ${ }^{66}$ In addition, Rimer $\mathrm{J}$ insinuated, in a divergence from the reasoning applied in both Trustor (No 2) and Trustor (No 3), that Burnstead Ltd held the disputed funds as a direct trustee for Dalby. Rimer J observed that Burnstead Ltd was 'in substance little other than Dalby's offshore bank account held in a nominee name,' and that Dalby had 'procured a payment of Gencor's money for his own benefit.' ${ }^{\prime 7}$ The learned judge stated 'Burnstead is simply a creature company used for receiving profits for which equity holds $\mathrm{Mr}$ Dalby to be accountable to [Gencor]. ${ }^{168}$ Rimer J did not, however, elaborate on the nature or extent of any prior equitable interest that may have been vested in the victim company, or on the juxtaposition between any such interest and equitable interest of Dalby. ${ }^{69}$

In considering the cases of Trustor and Gencor, both Lord Sumption and Lord Neuberger opined that the piercing issues alluded to in these cases were better explained by the concealment principle, albeit only Lord Sumption sought to justify this conclusion. Lord Sumption considered that the evasion principle had been erroneously employed in both

61 Also, see Shell International Trading \& Shipping Co. Ltd v Tikhonov [2010] EWHC 1399 (QB). Here a Mr.Tikhonov, in breach of his fiduciary duties to Shell, accepted bribes from a third party, the proceeds of which were paid directly, without ever passing into the hands of Tikhonov, into the accounts of T Capital Ltd; a company entirely under the control of Tikhonov. Shell sued to recover the amount of the bribe. Holding in favour of Shell, Jack $\mathrm{J}$ explained that '[t]he money was received by $T$ Capital and not by Mr Tikhonov. But it was received by $\mathrm{T}$ Capital at his direction and for his benefit. The corporate veil cannot here stand as a barrier between [Shell] and Mr Tikhonov, and Mr Tikhonov is to be held accountable as if he had received the money himself.' ([at 29]). It should be noted that Shell did not seek an order that Tikhonov and T Capital were jointly and severally liable, probably because it had already proven impossible for Shell to recover from T Capital via a default judgment.

62 It is to be observed that such a conclusion raises an anomaly in so far as liability for knowing receipt is generally regarded as attaching to a third party to a breach, see Williams $v$ Central Bank of Nigeria [2014] UKSC 10; [2014] AC 1189 [at 1197-1198] per Lord Sumption.

${ }^{63}$ Above $\mathrm{n} 18$.

${ }^{64}$ Burnstead Ltd was described, above n 18 per Rimer J [at 19], as being 'wholly owned and controlled by Mr Dalby'.

${ }^{65}$ As a consequence of breaching the conflict of interest duty, Dalby would have been ordinarily liable to account for any personal profit that he made, see Cook $v$ Deeks [1916] 1 AC 514. Yet in this instance, Burnstead Ltd took the profits directly and not Dalby (in Cook, it was found that the corporate opportunity was taken by the directors and transferred to the company, which took with notice of the victim company's equitable interest).

${ }^{66}$ Above $\mathrm{n} 18$ [at 744]. Note, however, that Rimer $\mathrm{J}$ did not justify this decision by means of an analysis of the prior veil piercing cases.

${ }^{67}$ Above $\mathrm{n} 18$ [at 745 ].

${ }^{68}$ Above $\mathrm{n} 18$ [at 744]. Rimer $\mathrm{J}$ also stated [at 750] that 'the Burnstead receipt represents a personal profit obtained by Mr Dalby in the course of acting as a director of ACP and for which he is accountable to ACP'. This again strongly suggests that Rimer $\mathrm{J}$ regarded the delinquent fiduciary as the beneficial recipient of bounty paid directly into the accounts of the device company.

69 This point is considered in more detail below, text to $\mathrm{nn} 106-109$. 
Trustor and Gencor because neither of these cases witnessed the device company's separate legal personality being used to evade an existing liability of its controller. Rather, the fruits of the controllers' breaches of duty were hidden behind the protective 'shields' of the device companies. ${ }^{70}$ Lord Sumption found, therefore that the controllers of the respective device companies were liable to account, not on the basis of the evasion principle, but on the basis that the device companies had received the money as the controllers' 'agent or nominee" 71

\section{The problematic nature of the 'agency solution'}

In Prest, Lord Sumption and Lord Neuberger both used agency law as the predominant relevant legal principle to explain the concealment principle (the 'agency solution'). ${ }^{72}$ Baroness Hale and Lord Wilson also favoured such an approach. ${ }^{73}$ It is to be observed that an ability to disturb the strict application of the Salomon principle by means of agency law principles was affirmed by the judgment of the Court of Appeal in Adams $v$ Cape Industries. ${ }^{74}$ In Adams, the Court considered that a piercing principle to disturb corporate personality was applicable only where 'special circumstances exist indicating that the company was a mere façade concealing the true facts. ${ }^{75}$ The Court of Appeal provided two distinct examples of a façade. The first was in a situation where a controlling shareholder of a company sought to evade a pre-existing legal obligation by hiding it behind the protective corporate shield of a registered company (now deemed the evasion principle). The second concerned an agency relationship, where a company acted as the agent of its controlling shareholder ${ }^{76}$ (post-Prest, an example of the concealment principle).

In a corporate context, an agency relationship may be tentatively defined as one based upon the express or implied consent of both the agent and the principal, whereby the agent is made subject to the principal's absolute control and will, to the extent that the agent conducts its business affairs without independence and does so to the ultimate benefit of its principal. ${ }^{77}$ In the context of a holding company-subsidiary relationship, the question of whether a subsidiary company (as a potential agent) is under the absolute control of its holding company may be determined by asking whether the subsidiary was but a 'puppet', totally manipulated by its master. If the subsidiary retains control over any of its 'own strings', the holding company will not be found to have exerted absolute control. In Adams, while the holding company exerted overall control of the policy directives of its wholly owned subsidiary, such control proved insufficient to justify an agency relationship, in so far as the subsidiary had authority to enter into its own contracts and was responsible for the day to day running of its own business. ${ }^{78}$

As a matter of theory, the corporate definition of an agency relationship could, however, be applicable equally to a company dehors a group relationship and, more

\footnotetext{
70 This point is advanced in the judgment of Lord Sumption, above $\mathrm{n} 4$ [at 485-486].

${ }^{71}$ Above $\mathrm{n} 4$ [at 487].

72 Above n 4 per Lord Sumption [at 487] and Lord Neuberger at [498-501].

${ }^{73}$ Above $\mathrm{n} 4$ [at 506].

${ }^{74}$ [1990] Ch 433.

75 Ibid [at 539] per Slade LJ, quoting from Woolfson v Strathclyde Regional Council 1978 SC (HL) 90 [at 96] per Lord Keith.

76 Ibid [at 542-548] per Slade LJ

77 See, for example, Garnac Grain Co Inc v. HMF Faure and Fairclough Ltd [1968] AC 1130 [at 1137].

$78 \mathrm{Had}$ the subsidiary disobeyed its holding company's policy directives in relation to exercising its apparent autonomy, it is most probable that the holding company would have required the subsidiary to return to business practices established and dictated by the holding company's policy initiatives. Yet in Adams, the contemplation of such a business practice did not warrant a finding of absolute control.
} 
significantly, could be applicable to a 'one-man type company'. In theory, 'one-man type companies could therefore be classed as being no more than agents of their controlling individuals on the premise that the controller inevitably exerted absolute control over the enterprise. But such a construction would contradict the accepted understanding of the incorporation of the company as a distinct legal entity which, possessed of a limited liability status, is, in law, responsible solely for obligations and liabilities entered into in its name. In all probability, the finding of an agency relationship in a 'one-man type company,' based upon absolute control, would lead to a proliferation of creditor and other third party claims to strike at the very heart of the limited liability concept by depriving the company's 'human' controller of the business incentives associated with a limited liability status. In the application of an agency solution, it is suggested that there are clear policy differences between 'one-man type companies' and groups of companies. In respect of the former, there is an obvious presumption that the controller exerts absolute control, whereas in a group of companies this is not the case. In a group situation, there must be cogent evidence to indicate absolute control on the part of the holding company.

In Salomon, the House of Lords emphatically denied an ability to found an agency relationship based upon an individual's absolute control over a 'one-man type company'. This denial was endorsed by the judgment of the Court of Appeal in Prest. For example, Rimer LJ opined that:

It is heretical to suggest that the total control that a single individual is (and will always be) entitled to exercise over the affairs of his one-man company is a feature resulting in the company's assets becoming assets to which he is entitled and therefore to which the company is not entitled."79

Accordingly, to avoid any potential conflict with the reasoning advanced by the House in Salomon, it is probable that, in Adams, the Court of Appeal impliedly sought to restrict the 'agency façade' to cases involving a group of companies. ${ }^{80}$

In short, it is contended that the future adoption of an 'agency solution' to underpin concealment cases involving 'one-man type companies' would be doctrinally nebulous, invoking a swift return to the unprincipled judicial treatment of 'piercing-type cases' which the Supreme Court Justices are so keen to avoid. The 'agency solution' would run contrary to Salomon, would be likely to propagate uncertainty in the law and could well precipitate a surge in litigation. In addition to the aforementioned criticisms of the agency solution, there

\footnotetext{
${ }^{79}$ Above $\mathrm{n} 4$ [at 445-446]. In Re Carey [1895] 2 QB 264 (a pre- Salomon decision), a sole trader,, (Carey) whose business was in severe financial difficulty incorporated a company and transferred the business assets to the company in consideration for a controlling interest in the company's share capital. Carey was subsequently made bankrupt. The trustee in bankruptcy successfully obtained a court order entitling the company's assets to be used to discharge Carey's personal debts in priority to the repayment of the company's creditors. In making such an order, Vaughan Williams $\mathrm{J}$ found that the newly incorporated company was Carey's agent, as Carey exercised absolute control over the company. Subsequently in Re Hirth [1899] 1 QB 612 (a post-Salomon decision, concerned with similar facts to those found in $R e$ Carey)) the Court of Appeal, in light of the judgment of the House of Lords in Salomon, no longer considered the decision in Carey to represent the law, namely, it was implicit from Salomon judgment that the controller of a 'one-man type company' could not be deemed liable for the company's debts on the basis of an agency argument founded on the premise that the controller exerted absolute control over the company's affairs.

80 The Court of Appeal was concerned with identifying the existence of a relationship between a group of companies that would amount to the finding of a single 'economic entity.' The Court concluded that the 'economic entity' relationship could not be sustained other than in circumstances substantiating an agency relationship. In Prest, the Supreme Court made no observations in relation to piercing issues in the context of groups of companies.
} 
are specific objections, discussed in the next part of this article, to the use of the law of agency to resolve cases such as Trustor and Gencor.

\section{UTILISING TRUST LAW TO JUSTIFY THE CONCEALMENT PRINCIPLE IN THE CONTEXT OF THE TRUSTOR-GENCOR LINE OF AUTHORITIES}

Several cases other than Trustor and Gencor have also involved instances of both a fiduciary and their device company being deemed jointly and severally liable for permitting the fruits of a breach of fiduciary duty to be exploited by a device company which was under the fiduciary's control. ${ }^{81}$ In the context of the 'Trustor-Gencor line' of cases, the purpose specific to this section of the article is to establish that principles of trust law, as opposed to principles of agency law, offer the explanation which is most likely to provide doctrinal stability in the deployment of the concealment principle.

Typically, in cases in the Trustor-Gencor line, the fiduciary of the victim company will breach the conflict of interest duty ${ }^{82}$ by either exploiting a corporate opportunity properly belonging to a victim company or by taking a secret commission or bribe. The fiduciary then conceals the fruits arising from the breach by diverting them to a device company. The assets in question, therefore, never pass into the hands of the delinquent fiduciary. The device company, having knowingly taken and retained the funds as a result of the delinquent fiduciary's breach of duty, holds the same subject to the victim company's prior equitable interest. The device company will therefore be susceptible to a proprietary claim by the victim company. ${ }^{83}$ It will also be liable in personam in equity; this is of particular utility to the victim company if, as is frequently the case, the fruits of the breach are not traceable. The device company may, however, have insufficient assets to discharge its liability to the victim company. In such circumstances, if the Salomon principle was followed strictly, the delinquent fiduciary would have no liability to account in equity because, according to the Salomon principle, the fiduciary, as a person separate and distinct from the device company, obtains no personal benefit from the mischief. As such, the victim company's ability to pursue a disgorgement remedy ${ }^{84}$ and recover the fruits of the breach will be dependent on overturning or circumventing the premise of the Salomon principle, and obtaining judgment against the delinquent fiduciary.

The judicial analysis and reasoning deployed to establish the fiduciary's potential liability in the Trustor-Gencor line of cases is marred by inconsistency. The sanctity of the Salomon principle has been overcome through the application of 'veil piercing', ${ }^{55}$ agency

\footnotetext{
81 See eg CMS Dolphin Ltd v Simonet [2001] 2 BCLC 704; Comax Secure Business Services Ltd v Wilson [2001] All ER (D) 222 (Jun); Shell, above n 61; Airbus, above n 9.

82 In respect of directors, the conflict of interest duty is now governed by the Companies Act 2006 ss.175-177. Prior to the codification of directors' duties by the Companies Act 2006, transactions involving a conflict of interest and duty were regulated as a rule of equity -see for example Regal Hastings Ltd v. Gulliver [1967] 2 AC 134 .This equitable rule was applied strictly and this strict interpretation is now incorporated into the terms of CA 2006, ss 175-177, see for example Towers v. Premier Waste Management Ltd [2012] BCC 72. In its simplest form, the conflict of interest duty may be described as a duty of loyalty and fidelity which prohibits a director of a company from exploiting a corporate opportunity, corporate property, corporate information or his/ her own corporate position, to his/her own potential advantage.

83 FHR Europe Ventures LLP v Cedar Capital Partners LLC [2014] UKSC 45 [2014]; 3 WLR 535.

84 Note that P Davies, Gower and Davies, Principles of Modern Company Law (London: Sweet \& Maxwell, $8^{\text {th }}$ edn, 2008) p.580 points out that, in cases in which 'a profit arises out of a contract between the director and a third party... an account of profit will be the sole remedy.'

85 See eg, Trustor (No 2), above n 18; Gencor, above n 18.
} 
law ${ }^{86}$ and trust law. ${ }^{87}$ In some instances, albeit recognising a need to disturb corporate personality, the courts have provided no specific legal principle to justify the fiduciary's liability. ${ }^{88} \mathrm{~A}$ recent example of this lacuna is evidenced in Airbus Operations Ltd $v$ Withey, ${ }^{89}$ in which Havelock-Allan $\mathrm{J}$ found that that the controller of a device company, together with the device company itself, were jointly and severally liable to account for receiving a secret commission in breach of contractual and fiduciary duties owed by the controller to the victim company. This finding required the court to treat the payments to the device company as if they were payments to its controller. ${ }^{90}$ Havelock-Allan $\mathrm{J}$ held that this case fell within Lord Sumption's concealment principle and that the court was thus entitled 'to look beyond the corporate veil, without piercing it." 11 Accordingly, the device company was treated as the 'alter ego or nominee' 92 of its controller. Havelock-Allan $\mathrm{J}$ did not, however, offer any specific explanation of how or why such an agency or trusteeship may have arisen.

In addition to the general doctrinal objections to the agency argument that have already been advanced in this paper, there are other specific objections to the use of the law of agency to resolve cases in the Trustor-Gencor line. If, as was suggested in Prest, the device company in Trustor took the disputed funds as agent for its controller (the delinquent fiduciary), it is difficult to explain the in personam liability of either. If the controller took as principal, then he would prima facie have been liable for the primary breach of the duties that he owed to the victim company. But liability for the primary breach was a matter outside of the court's jurisdiction. ${ }^{93}$ Furthermore, if the device company took as agent, then, having taken in a ministerial capacity, it would not have been susceptible to any in personam liability for knowing receipt. ${ }^{94}$

As regards other cases in the Trustor-Gencor line, the agency solution would mean that the controller would be regarded as having received the fruits of his own breach, and would be liable in personam, simply on the basis that he had received the benefit accruing from his own breach of duty. The device company, having only ever taken or dealt with the disputed funds in its capacity as agent, could only potentially be liable in personam in equity as a dishonest assistant. ${ }^{95}$ The weight of authorities suggests, however, that a party who dishonestly assists in a gain-based breach of fiduciary duty is only liable in personam to account for his own gains, not for those of the primary wrongdoer ${ }^{96}$ It is therefore difficult to see how the finding of an agency relationship can justify the orders of joint and several

86 In Prest, above $\mathrm{n} 4$ [at 745], the cases of Trustor (No 2), above n 18.and Gencor, above $\mathrm{n} 18$ were explained as cases invoking agency law principles.

87 Trustor (No 3), above n 56.

${ }^{88}$ Also see, Shell, above n 61, and CMS Dolphin, above n 81.

${ }^{89}$ Above $\mathrm{n} 9$.

90 By analogy, this reasoning was akin to that found in Trustor (No2), above $n 18$.

${ }^{91}$ Above $\mathrm{n} 9$ [at 461] per Havelock-Allan J.

${ }^{92}$ Above $\mathrm{n} 9$ [at 461] at per Havelock-Allan J.

${ }^{93}$ See above, text to $\mathrm{n} 45$.

${ }^{94}$ As Davis \& Virgo remark '.... party who receives property as an agent cannot be sued for his receipt, since he only holds the property ministerially, for the benefit of another' (P Davis \& G Virgo, Equity \& Trusts Text, Cases and Materials (Oxford: Oxford University Press, 2013) p 904). See also, Agip (Africa) Ltd $v$ Jackson [1991] Ch 547. Note that, in Trustor (No 2), above $\mathrm{n} 18$, it was held that the device company was liable in personam for knowing receipt.

${ }^{95}$ See Agip, Ibid, for an example of parties who took the disputed funds as agents being held liable for dishonest assistance. On dishonest assistance generally, see Twinsectra $v$ Yardley [2002] 2 A.C. 164 $(\mathrm{HL})$, as interpreted in Barlow Clowes International Ltd v Eurotrust International Ltd [2005] UKPC 37; [2006] 1 WLR 1476 (PC).

${ }^{96}$ See in particular Ultraframe v Fielding [2005] EWHC 1638 (Ch) [at 1595-1601] per Lewison J. 
liability to account in equity, albeit that such orders were actually made in the majority of the Trustor-Gencor line of cases. ${ }^{97}$

It follows that the acceptance of the agency solution would be detrimental to future claimants in cases following the Trustor-Gencor line because such claimants should not have a potential claim against the agent for equitable in personam liability. ${ }^{98}$ Here the claimant's detriment would be compounded where, for example, the assets were untraceable so that a proprietary claim could not be brought against the device company. ${ }^{99}$

In justifying the application of trust law to the Trustor-Gencor line of cases, it is contended that the fiduciary's liability may potentially be founded on two distinct trust-based arguments. First, as evidenced in the judgment of Rimer $\mathrm{J}$ in Gencor, that the device company took the asset on trust for its controller. According to this argument, the controller's liability springs from him or her being regarded as the recipient of the equitable title to the disputed asset and therefore, in the eye of equity, as the person who took the benefit in breach of his or her fiduciary duties. Alternatively, following the obiter comments of Scott VC in Trustor (No3), liability may be established on the premise that the device company took the asset on trust for the victim company and the delinquent fiduciary dishonestly assisted in the breaches of trust perpetrated by the device company in dissipating the trust property.

Pertinently, applying trust law to challenge issues around the sanctity of corporate personality is not a new concept, for, in Salomon itself, the Court of Appeal held against $\mathrm{Mr}$ Salomon on the basis that A Salomon \& Co Ltd had taken the assets 'as trustee for him'. 100 Whilst the House of Lords overturned the Court of Appeal's ruling, it did so on the premise that there was insufficient evidence to recognise a trust relationship and not because it was infeasible for a company to be considered a trustee for its controller. As Lord Davey remarked:

There was certainly no express trust for the appellant; and an implied or constructive trust can only be raised by virtue of some equity. I took the liberty of asking the learned counsel what the equity was, but got no answer. ${ }^{101}$

\section{The 'trust solution': a solution based on the establishment of a trust between the device company and the controller}

Cases within the Trustor-Gencor line may potentially be explained on the basis that the device company took the fruits of its controller's breach as trustee for its controller (hereafter referred to as the 'trust solution'). This view, implicit in the comments of Rimer $\mathrm{J}$ in Gencor, is superficially attractive and has attained some academic support. ${ }^{102}$ The trust solution would

97 The liability orders amounted to joint and several liability of both the fiduciary and the device company in, for example, Trustor (No 2), above n 18; Gencor, above n 18; Airbus, above n 9.; CMS Dolphin, above n 81; Comax, above n 81.

98 There could be obvious benefits of claiming in personam against the device companies, especially if the device company was solvent and had assets, see, for example, Airbus, above $\mathrm{n} 9$.

99 Furthermore, if such cases were decided by way of an agency solution, creditors other than the claimant such as, for example, the Inland Revenue, would also be obliged to claim against the controller as opposed to having the option of pursuing the claim against both the controller and the device company.

100 Broderip v Salomon [1895] 2 Ch 253 [at 338] per Lindley LJ.

101 Ibid [at 56].

102 For academic explanations in support of this view, see S. Watson 'Two Lessons from Trustor' (2003) 119 LQR 13 at 16 . Watson regards Smallbone (the controller) as being ' $[$ t]he ultimate 
render both the device company and its controller liable. The controller would be liable in personam ${ }^{103}$, having received the assets beneficially following his breach of a fiduciary duty, and the device company (the trustee) could be liable in personam for knowing receipt on the basis that, as a trustee, it was 'carry[ing] on business as a principal.' ${ }^{104}$ The victim company could thus potentially claim against both controller and device company, or either.

Within the context of the Trustor-Gencor line of cases, the trust solution is, however, subject to fundamental flaws which diminish its ability to satisfy the demands of a doctrinal platform for the concealment principle which promotes clarity, stability and predictability. First, when misappropriated assets, incidental profits or secret commissions are taken in breach of a fiduciary duty, from the moment of the breach, the beneficial interest in these assets belongs to the principal. Hence, in the cases considered here, the beneficial interest in the fruits of the breach should vest immediately in the victim company. ${ }^{105}$ The only plausible means to overcome this objection would be to regard the controller as having taken the beneficial interest in the disputed asset as an 'intermediate trustee', subject to a sub-trust in favour of the victim company. Here, the device company would take the asset on trust for its controller, making both liable, whilst the victim company would, ultimately, be entitled to the beneficial interest. ${ }^{106}$ While it may be plausible for a court to find that a beneficiary took the beneficial interest on sub-trust for another party, ${ }^{107}$ this type of arrangement appears artificial because, as a matter of ordinary equity, it is difficult to explain the existence of the sub-trust when the device company would, as previously noted, be expected to simply take legal title subject to the victim's prior equitable interest. ${ }^{108}$

Furthermore, the law of sub-trusts is not entirely settled; it is arguable that when a sub-trust is said to arise, in fact, the primary trustee (i.e. the device company) holds directly on trust for the beneficiary of the sub-trust (the victim company), creating, in effect a conventional trust between these two parties, with the effect of excluding the intermediate

beneficial receiver' of all of the money paid at his behest by Trustor to Introcom (the device company as trustee). See also Tan Heng-Han 'Veil piercing - a fresh start' [2015] 1 JBL 20 at 24. Heng - Han explains Trustor and Gencor as cases in which the [device] company, not being the true owner, would merely have held the [fruits of the breach] on trust for the real owner [ie, its controller]'.

${ }^{103}$ Although not for knowing receipt, as this is a liability placed upon a third party to the breach of trust or fiduciary duty, rather than upon the primary perpetrator of the breach of fiduciary duty. This point was apparently overlooked in Trustor (No 2), above n 18.

104 Above n 100 per Lindley LJ [at 338]. Lindley LJ was explaining that the position of a trustee is contrary to that of an agent. The latter carries on business solely for his principal and is therefore not susceptible to in personam liability, whereas the former carries on business as a principle, but subject to the beneficiary's beneficial interest and the duties associated with trusteeship. According to this reasoning, a trustee could potentially be made liable for knowing receipt.

105 Indeed in Trustor (No 2), above n 18, it was held that as a consequence of Smallbone's breach of duty, Introcom's receipt of the fruits of that breach made it a constructive trustee for Trustor. In FHR Europe, above $\mathrm{n} 83$, it was held that bribes and secret commissions are held on constructive trust for the principal or beneficiary. In Boardman v Phipps [1967] 2 AC 46, it was held that incidental profits are held on constructive trust for the principal or beneficiary.

106 This might be what Rimer J had in mind in Gencor, above $\mathrm{n}$ 18. As explained above, text to $\mathrm{n} 58$, Rimer $\mathrm{J}$ seemed to suggest that the device company took on trust for its controller (the delinquent fiduciary). In Prest, above n 4, Lord Sumption, [at 486], suggested that Rimer J had been mindful of the 'prior equitable interest' of the victim company. So maybe Rimer $\mathrm{J}$ took the view that the device company took on trust for the controller who, in turn, took his equitable interest subject to the victim company's prior equitable interest.

107 See Nelson v Greening \& Sykes (Builders) Ltd [2007] EWCA Civ 1358.

108 There is no existing authority which directly supports the establishment of such a complex arrangement in the Trustor-Gencor line of cases although it may be queried whether in Prest, above $\mathrm{n}$ 4 [at 486], Lord Sumption in his explanation of Gencor, was obliquely referring to such an arrangement. The existence of a sub-trust which was a resulting trust was recognised in Nelson, above $\mathrm{n} 107$. 
trustee (the delinquent fiduciary) altogether. ${ }^{109}$ If this does represent an accurate description of the law, then the trust solution is incapable of explaining why in personam liability falls upon the delinquent fiduciary.

Assuming, however, that the finding of a sub-trust could justify the delinquent fiduciary's liability, it is still necessary to determine the type of 'primary trust' that arises between the device company and its controller and on what grounds such a trust should arise. ${ }^{110}$ An express trust would appear to be an unlikely candidate. While an express trust of personalty may be inferred from the conduct of the parties in the absence of an actual declaration of trust, ${ }^{111}$ the Salomon case is itself authority for the proposition that mere control alone is insufficient justification for the inference of an express trust, or indeed any other type of trust between a company and its controller. ${ }^{112}$ Furthermore, if the victim company's assets included land, any express trust, to be enforceable, would need to be evidenced in writing. ${ }^{113}$ Establishing the 'primary trust' as a resulting trust would fare little better. In a situation where an asset is diverted from the victim company to the device company, there is simply no ground for the imposition of a resulting trust in favour of the controller unless the device company's controller gave consideration for the diversion, resulting in effect, in a purchase by the controller from the victim company in the device company's name.

In light of the foregoing reasoning, any trust by which the device company took the assets as trustee for the delinquent fiduciary would have to be a constructive trust. Providing doctrinal justification for a constructive trust arising in such circumstances is not, however, straightforward. It could be argued that a constructive trust may arise based on the device company's unconscionable retention (and subsequent disposal) or fraudulent receipt of the assets. ${ }^{114}$ But a seemingly intractable obstacle to this argument is that constructive trusts of this type arise in favour of the party regarded in equity as the rightful owner of the disputed property. ${ }^{115}$ Thus, were such trusts be applied to Trustor-Gencor type cases, the beneficial interest would surely vest in the victim company, rather than the delinquent fiduciary.

The only other type of constructive trust that may be applicable is the "common intention' constructive trust. ${ }^{116}$ In cases within the Trustor-Gencor line, it could be contended that the fiduciary procured the transfer of the misappropriated assets to the device company with the ultimate intention of benefiting personally from this scheme and, by applying

109 This issue is discussed in Nelson, above $\mathrm{n}$ 107. It was suggested by Lawrence Collins LJ in Nelson that the legal status of the sub-trust may be recognised, but the authorities are equivocal on this point. See the discussion on this point in Nelson [at 52-58].

110 At this point, it is useful to refer back to Lord Davey's observation- see above, text to n 101.

111 See, for example, Re Kayford [1975] 1 WLR 279.

112 See especially the comments of Lord Davey in Salomon, above $\mathrm{n} 2$ [at 55].

113 Law of Property Act 1925, s 53(1)(b).

114 These categories of constructive trust were recognised by the House of Lords in Westdeutsche Landesbank Gironzentrale v Islington LBC [1996] AC 669. In respect of fraudulent receipt, see Lord Browne-Wilkinson's discussion under the heading, 'the stolen bag of coins' [at 715-716].

115 Usually a party who has transferred property in error, or who has been fraudulently induced to transfer property. See Westdeutsche, ibid.

116 There is post-Prest authority that a 'common intention' constructive trust may arise in a quasicorporate setting. In M v M [2013] EWHC 2534 (Fam), upon a wife's application for ancillary relief, it was held that several companies under the husband's control held various properties subject to a 'common intention' constructive trust in his favour on the ground that 'the [controller] intended to retain each beneficial interest in the properties and it therefore follows inexorably that it was also the intention of the [device] companies' ([at 551] per King J In Crossco No 4. Unltd v Jolan Ltd [2011] EWCA Civ 1619; [2012] All ER 754, it was recognised by the Court of Appeal that the principles relating to 'common intention' constructive trusts may be employed outside of the context of the family home. 
attribution principles, ${ }^{117}$ it may be open to the court to find that it was the common intention of both the fiduciary and the device company that the fiduciary was to take the ultimate benefit of the scheme. By following this line of reasoning, it could be asserted that the device company obtained legal title to the assets but took subject to a 'common intention' constructive trust for the controller, who took this beneficial interest subject to the victim company's prior equitable interest. Although it has been recognised, since Prest, that a common intention constructive trust may arise between company and controller, ${ }^{118}$ there is no authority which supports the recognition of a 'common intention' constructive trust in circumstances where the beneficial interest arising therefrom is held on sub-trust for, or is susceptible to a prior equitable proprietary interest belonging to, another party. Furthermore, in cases of this nature, one should also pay heed to the comments of Lord Walker, who in In Prest, warned against the 'false invocation of equity.' 119 Indeed, as the constructive trust is far more flexible than express and resulting trusts, it may be susceptible to being the subject matter of inappropriate attempts to resolve jurisprudential problems through the use of trust law. On balance, therefore, it is suggested that, whilst the trust solution may provide a theoretical means to resolve cases within the Trustor-Gencor line, it is a solution fraught with complications and uncertainties.

\section{The 'accessory solution': a solution based on dishonest assistance}

Given the aforementioned objections to the adoption of the 'trust solution', it is contended that, if principles of trust law are to be capable of providing a solution to the Trustor-Gencor line of cases in a manner which does not fall prey to the doctrinal defects which have been highlighted above, then this solution must be found in the form of 'the accessory solution', that is, the solution advocated by Scott VC in Trustor (No 3) ${ }^{120}$. If the analysis advanced by Scott VC is applied to cases within the Trustor-Gencor line, then the device company can be regarded as having taken the bounty arising from the delinquent fiduciary's breach subject to the victim company's prior equitable interest (described by Scott VC as arising by virtue of a constructive trust). The device company is liable in equity for any improper use of this 'bounty', such as making payments to third parties. The delinquent fiduciary, having dishonestly assisted in the device company's breach of its equitable obligations, is jointly and severally liable with the device company. ${ }^{121}$

In order to establish that the accessory solution may advance the concealment principle in future cases within the Trustor-Gencor line without propagating doctrinal confusion, it is necessary to address, in particular, two issues. First, it is necessary to establish the type of trust or equitable obligation which was breached by the device company. This is especially important because the in personam liability of the delinquent fiduciary turns on his or her accessorial liability for this breach. In Trustor (No 3), Scott VC was equivocal as regards the precise nature of the nature of the breach committed by Introcom. One possibility is based on knowing receipt. Although knowing recipients are no longer regarded as constructive trustees, ${ }^{122}$ it is generally accepted that, whatever properly called, a knowing recipient has a

\footnotetext{
117 Discussed below, see $\mathrm{n} 129$ and accompanying text.

$118 M v M$, above $\mathrm{n} 116$.

119 See the comments of Lord Walker in Prest, above $\mathrm{n} 4$ [at 509].

120 Above $n$ 56. See above, text to nn 56-59.

${ }^{121}$ Authorities that, in English law, a dishonest assistant is jointly and severally liable with the party whom he has assisted in a loss-causing breach (within this context, the device company's breach of the equitable obligations subject to which it took the property), include Trustor (No 3) itself and Grupo Torras SA v Al-Sabah (No 5) [2001] CLC 221. More generally, see S Elliott and C Mitchell, 'Remedies for Dishonest Assistance' (2004) 67(1) MLR 16.

122 Williams, above $\mathrm{n} 62$.
} 
duty 'to restore the assets immediately. ${ }^{123}$ It is therefore quite possible that Scott VC had in mind that the delinquent fiduciary was liable for dishonestly assisting with the device company's breach of this core duty that it had assumed in its capacity as a knowing recipient. ${ }^{124}$ Alternatively, the device company could be made a constructive trustee for the victim on the ground of unconscionable retention or fraudulent receipt of the assets. ${ }^{125}$ Although these trusts usually arise within the context of mistaken payments, it would, it is submitted, be difficult to argue that the device company, having received and retained the funds in pursuance of a clandestine scheme, does not take with its conscience sufficiently affected to be regarded as a constructive trustee for the victim company. ${ }^{126}$ Given the blatancy of the wrongdoing in Trustor, it may well be that this is the kind of constructive trust to which Scott VC was referring. ${ }^{127}$ Regardless of which of these two proposed constructions is preferred, it is submitted that both provide ample justification for establishing the liability of the device company and of the delinquent fiduciary.

Secondly, it is necessary to address whether the rules of attribution permit the delinquent fiduciary's state of mind to be 'double-counted' so as to establish the requisite malus animus of both of the separate legal persons involved in the mischief, that is, by attributing the device company with its controller's knowledge. The relevant rules of attribution, which were explained succinctly by Lord Hoffmann in Meridian Global Funds Management Asia Ltd $v$ Securities Commission, ${ }^{128}$ are readily applicable to device companies through the ordinary application of attribution rules. As Scott VC put it, '... it is through Mr Smallbone that the requisite knowledge of the impropriety of the payments from the Trustor account is properly to be imputed to Introcom.' ${ }^{129}$ The liability of the delinquent

123 Williams, above $\mathrm{n} 62$ [at 1208] per Lord Sumption. The extent of the duties of knowing recipients has been explored in more detail by certain commentators. See, for example, C Mitchell and $S$ Watterson 'Remedies for Knowing Receipt' in C Mitchell (ed.), Constructive and Resulting Trusts (Oxford: Hart, 2009), at pp.115-158. In particular, Mitchell and Watterson state (at p.130) that 'equity fixes them with custodial duties which are the same as some of the duties which are voluntarily assumed by express trustees', and further that 'a knowing recipient's core duty, and generally his only duty of practical significance, is to restore the misapplied trust property'.

${ }^{124}$ Especially when it is borne in mind that a liability for dishonest assistance is not restricted to cases concerning assistance with breaches of trust. For a specific authority that a knowing recipient can be liable in his own right for a breach of trust, see Perry $v$ Knott (1841) 4 Beav 179.

${ }^{125}$ See above $\mathrm{n} 114$.

126 In this sense, a 'constructive trustee' means a party who would still, after Williams, be referred to as a constructive trustee and who owes a fuller range of duties than what is owed by a mere knowing recipient (see R C Nolan 'Equitable Property' 122 LQR (2006) 232).

127 Notably, the view that a knowing recipient is not a trustee was widely accepted at the time of Trustor (No 3)- see Paragon Finance plc v Thakerar \& Co [1999] 1 All ER 400, and was likely known to the members of the Court of Appeal who sat in Trustor (No 3). This, perhaps adds weight to the second construction proposed here.

128 [1995] BCC 942. Lord Neuberger classified the attribution rules into three distinct categories. The primary rule of attribution provides that a company must necessarily have attributed to it the state of mind of its directing organ under its constitution; (ii) attribution rules may further be determined by general principles of agency whereby the directing organ of the company (ordinarily the company's board), delegate to an individual, the 'directing mind' of the company in a specific matter(s), by way of an actual, implied or ostensible authority and finally; (iii) attribution may be deployed exceptionally in special circumstances, namely where the court is required to fashion a special rule of attribution for a particular substantive rule.

129 Trustor (No 3), above n 56 [at 64]. See also Bilta (UK) Ltd (in liquidation) v Nazir (No 2) [2015] UKSC 23, [2015] 2 WLR 1168, in which the Supreme Court approved the application of the attribution rules in accordance with the classification so expressed by Lord Neuberger in Meridian Global, Ibid. The Court concluded that where a third party claim against a company (e.g. for knowing receipt) arose as a result of the misconduct of a director or other agent of the company, the company would be attributed with the act and state of mind of the director or other agent. It should also be noted that $M \vee M$, above $\mathrm{n} 116$, is a direct authority that the intention of the controller of a company can be 
fiduciary himself depends on evidence of his misconduct. ${ }^{130}$ By 'double counting' the delinquent fiduciary's conscience to establish both his own state of mind and that of the device company, Scott VC's solution neatly sidesteps the contentious question of whether the device company's corporate veil should be pierced.

At the time of Trustor (No3), this 'double counting' was novel within the context of cases relating to issues concerned with the sanctity of the corporate veil. Similar reasoning has been employed subsequently by Seymour QC in Comax Secure Business Services Ltd $v$ Wilson ${ }^{131}$ and by Norris $\mathrm{J}$ in The Law Society of England and Wales v Habitable Concepts Limited $^{132}$ although in neither case was Scott VC's reasoning cited. ${ }^{133}$ It is nevertheless submitted that an ability to 'double count' the directing mind of a company should be regarded as acceptable, logical and relevant where, as in the context of the Trustor-Gencor line of cases, the liability of both the company and its controller is derived and defined as a consequence of their distinct responsibilities. For example, and by way of analogy, the requisite state of knowledge of both the company and its directing mind may be double counted' to convict both the company and its directing mind for the offence of common law conspiracy providing the conspiracy in question involves at least one other culpable independent third party. ${ }^{134}$ The conviction against the company and its directing mind would not be possible, however, without the involvement of an independent third party because, by definition, the offence of conspiracy necessarily requires the interaction of at least two independent minds conspiring together. ${ }^{135}$

There are further respects in which the accessory solution stands up to scrutiny in its ability to underpin the concealment principle in a clear and principled manner. Most significantly, the accessory solution is not inconsistent with Salomon and does not seek to 'pierce the corporate veil' or disturb corporate personality by manipulating a legal mechanism (agency or trust) to the objective of 'artificially' imposing a 'like liability' on a

imputed onto the company itself for the purposes of establishing a constructive trust (albeit, in this case, a 'common intention' constructive trust).

130 In all of the existing cases within the Trustor-Gencor line, the dishonesty necessary to establish the delinquent fiduciary's liability for what is now generally referred to as 'dishonest assistance', would readily be established. The test for dishonestly is considered primarily to be an objective one and equates to a conscious impropriety or a reckless disregard of the rights of others rather than mere negligence or oversight. As such it is sufficient that the dishonest assistor was aware that his participation in the arrangement was contrary to normally acceptable standards of honest conduct, see Royal Brunei Airlines v Tan [1995] 2 AC 378 and Twinsectra, above n 95 as interpreted in Barlow Clowes, above n 95.

131 [2001] All ER (D) 222. In Comax, a Mr. Coker (C), a director of Comax, obtained secret commissions. Coker was assisted in this task by a Mr Wilson, formerly a senior employee of Comax. The secret commissions resulting from Coker's breach of duty were paid directly to Nemesis plc, a company under Wilson's control. Coker, Wilson and Nemesis plc were all held to be jointly and severally liable to account for the profits. Coker was held liable as the fiduciary in breach, Nemesis plc as a knowing recipient and Wilson (the directing mind of Nemesis plc) as a dishonest assister.

132 [2010] EWHC 1449 (Ch). Here, funds were paid to a device company in breach of trust. The device company dissipated the funds. The device company was found liable in personam for knowing receipt. The device company's state of mind was ascertained via its controller. The claimants sought to pierce the corporate veil to a conclusion that the controller should be liable for knowing receipt. In advancing this argument, both Trustor (No 2), above n 18 and Gencor, above n 18, were cited as supporting authorities. This argument was defeated, however, on the premise that there was insufficient evidence to establish that the device company was deliberately being used as a façade. Instead, Norris $\mathrm{J}$ held the controller liable for dishonestly assisting in the breaches of trust by which the device company obtained the funds.

133 Trustor (No 3), above n 56, was not cited in either Comax, above n 132 or Habitable Concepts, ibid.

${ }^{134}$ See, for example, $R$ v IRC Haulage [1944] 1 All ER 691.

135 See eg, McDonnell [1966] 1 QB 233. 
company and its controller. Furthermore, in contrast with an agency solution, the stringency of the requirement to prove dishonesty on the controller's part ${ }^{136}$ would preclude the accessory solution from being the catalyst for a proliferation of cases in which the corporate veil could be circumvented. ${ }^{137}$

A further advantage to the accessory solution is that, unlike the agency or trust solutions, it may provide an avenue for relief even in cases in which the delinquent fiduciary does not have absolute control of the 'device company.' ${ }^{138}$ This may be useful in cases such as CMS Dolphin ${ }^{139}$ where, for example, the delinquent fiduciary diverts a corporate opportunity to a company which operates as a 'quasi-partnership' rather than being subject to his/her complete control. The company's in personam liability could be established through the knowledge of its controlling minds (so long as the business partner knew of the scheme), and the delinquent fiduciary (and/or the partner) could be liable for dishonest assistance in respect of dispositions of by the company of the fruits of the breach.

Finally, it should be noted that, until recently, the decision of the Court of Appeal in Sinclair Investments (UK) Ltd $v$ Versailles Trade Finance $L t d^{140}$ provided a substantial obstacle to the deployment of the accessory solution in cases involving breaches of fiduciary duty by way of secret commissions or bribes. In Sinclair, it was held that a fiduciary, having taken a bribe or secret commission, was liable to account in personam to his principal, but did not hold the proceeds of such a breach of duty on constructive trust (or any other type of trust) for the principal. The reasoning in Sinclair would negate the operation of the accessory solution in cases where the delinquent fiduciary caused a bribe or a secret commission to be paid to a device company under his control; it would be difficult to argue that the device company took the secret commission on trust for the victim company when there would have been no trust had the secret commission been paid directly to the delinquent fiduciary. This state of affairs was remedied, however, by the recent decision of the Supreme Court in FHR European Ventures LLP $\vee$ Cedar Capital Partners LLC, ${ }^{141}$ in which it was held that a fiduciary does indeed take bribes and secret commissions on constructive trust for his principal.

Overall, it is submitted that the accessory solution should be employed to advance the concealment principle in future cases within the Trustor-Gencor line. Of all of the potential solutions by which the concealment principle may be effectuated in Trustor-Gencor-

\footnotetext{
136 See above $\mathrm{n} 130$.

137 In cases falling within the Trustor-Gencor line, the participation by the controller in the dissipation by the device company of the victim company's property will usually be flagrantly dishonest. In Trustor (No 3), above $\mathrm{n} 56$, Scott $\mathrm{VC}$ routinely reached the conclusion that the controller had been dishonest, as did Seymour QC in Comax, above n 81. In Airbus, above n 9, although the controller was not held to be a dishonest assister, other parties who did not owe fiduciary duties to the victim company but who had engaged in similar activities to the controller were held to have dishonestly assisted him. Furthermore, in Shell, above n 63, CMS Dolphin, above n 81, and Gencor, above n 18, the trial judges made it clear that they regarded the fiduciaries' conduct to have been dishonest.

138 It should be emphasised that, without the absolute control of the delinquent fiduciary, the device company could not be regarded as his/her agent or trustee.

139 Above $\mathrm{n}$ 81. Note that, in CMS Dolphin, the delinquent fiduciary initially set up a partnership and misappropriated the victim company's corporate opportunities in favour of the partnership. The partnership was then incorporated, and the benefit of the contracts in question was transferred to the company. The court held, following Cook v Deeks [1916] 1 AC 554, that the device company had taken with notice that the contracts had been obtained in breach of fiduciary duties, and liability of the company and the delinquent was established on this basis. One of the contracts, however, was diverted directly to the device company. In respect of this contract, the reasoning in Cook cannot apply, and CMS falls within the Trustor-Gencor line.

140 [2011] EWCA Civ 347.

141 Above n 83.
} 
type cases, the accessory solution is the one best equipped to bring about the doctrinal perspicuity to which the Supreme Court has attached such importance.

\section{CAN TRUST LAW BE UTILISED TO JUSTIFY CASES OTHERWISE FALLING WITHIN THE EVASION PRINCIPLE?}

The final part of this article will contend that the law of trusts, via the constructive trust, can provide a persuasive justification for the decisions in the previously decided cases exhibiting an otherwise correct procedural application of the evasion principle, namely the cases of Gilford and Jones. ${ }^{142}$ It will nevertheless be recognised that the adoption of a currently recognised type of constructive trust for this purpose (application of the concealment principle) might encourage undue erosion of the Salomon principle. Accordingly, the final part of this paper will suggest that it is unnecessary to retain veil-piercing in the guise of the evasion principle but rather that the constituent elements of that principle can and should be explained, to an objective of providing clarity, simplicity and certainty, through the use of a distinct and exclusive species of constructive trust. It will further be argued that, in the future advancement of the law, the court's ability to disturb corporate personality could legitimately, through the application of such a trust, be extended beyond the ambit of the current evasion principle so as to prevent all fraudulent and intentional abuses of the incorporation process. ${ }^{143}$

If principles of trust law are to provide an alternative to the application of the equitable piercing doctrine in cases ostensibly concerning the evasion principle, the actual trust solution must provide the answer. The accessory solution is of no relevance here because it is dependent upon a diversion of an asset to the device company by its controller in breach of the controller's fiduciary duties owed to a victim company. By contrast, the evasion principle is only applicable in circumstances in which a device company is used to evade an existing specific obligation of its controller. The application of the accessory solution is clearly disparate from the application of the evasion principle.

\section{Are Gilford and Jones cases of trusts?}

As has been noted, although the equitable piercing principle was invoked in Gilford and Jones, both are sometimes viewed as agency cases. The courts in both cases relied on Smith $v$ Hancock ${ }^{144}$ as authority for the conclusion that the company controlled by the wrongdoer was 'a mere cloak or sham', a 'mere device'. ${ }^{145}$ Although such descriptions may

\footnotetext{
142 It is highly improbable that the evasion principle could ever be correctly applied in a situation involving a group of companies, namely to pierce the corporate veil of a company which was a subsidiary of its holding company. Here in the context of the operation of the evasion principle, any existing legal obligation which the holding company wished to hide behind its subsidiary company would, in all probability, have been a legal obligation entered into by the subsidiary company or another subsidiary company under the control of the holding company rather than an obligation entered into by the holding company itself, see eg, Ord v. Belhaven Public Houses Ltd [1998] 2 BCLC 477.

${ }^{143}$ For discussion of fraudulent and intentional abuses of the incorporation process which fall outside of the current scope of the evasion principle, see below n 177-179 and accompanying text.

144 Above $\mathrm{n} 33$.

145 Gilford, above n 18 [at 961] per Lord Hanworth; Jones [1962], above n18 [at 838] per Russell J.
} 
often be interpreted as metaphors for an agency relationship, ${ }^{146}$ it is arguable that they actually suggest that the device company was a trustee for the controller. In Smith, ${ }^{147}$ Lindley LJ observed that the court would have 'grant[ed] the Plaintiff relief' had there been sufficient evidence 'that what was being done was a mere cloak or sham, and that in truth the business was being carried on by the wife and Kerr for the Defendant, or by the Defendant through his wife for Kerr'. ${ }^{148}$ Although he did not expressly state whether such relief would have been founded on a trust or an agency relationship, Lindley LJ explored this precise issue in the Court of Appeal in Salomon. ${ }^{149}$ Here, he described companies such as A Salomon \& Co. Ltd, having been incorporated or used for improper purposes, as 'mere devices'. ${ }^{150}$ He held that such companies should be properly regarded as trustees, rather than agents, for their controllers. This illuminates Lindley LJ's judgment in Smith to a conclusion that, had the business in Smith been a 'sham, a device', it seems likely that Lindley LJ would have found that Mrs Hancock carried on business as trustee for her husband. Furthermore, the repeated use of the term 'device' in Gilford and Jones assumes increased significance in light of Lindley LJ's insistence that a 'device' company is trustee for its controller. It is worth recalling that, in Salomon, although the Court of Appeal's finding that the company was a device or sham was overruled, the House of Lords did not completely rule out the possibility of a 'one-man type company' being held trustee for its controller. ${ }^{151}$ It is therefore arguable that Gilford and Jones are best interpreted on the footing that the device companies held the controller's business, and took the disputed land, as trustees for Horne and Lipman respectively.

An issue specific to Jones is that, if it is to be regarded as a case concerning the evasion principle, then an explanation is required as to how this justifies disregarding not only the separate personality of the device company, but also the Land Registration Act 1925. The land in question was registered land, and Jones had not protected his estate contract by entry on the appropriate register of title. According to the Land Registration Act, unprotected estate contracts were unenforceable against a purchaser for value. ${ }^{152}$ The specific performance order against the device company has been explained on the ground that it took the land with notice of the estate contract. ${ }^{153}$ But the doctrine of notice did not apply to registered land. ${ }^{154}$ Pertinently, however, concerns regarding the applicability of the Land Registration Act would have been obviated had the company been regarded as having

\footnotetext{
146 See, for example, above, n 28 and 29 and accompanying text.

147 Here a grocer, a Mr Hancock, sold his business to the plaintiff. The sale agreement included a restraint of trade covenant. Shortly after the sale, Hancock's wife set up a grocer's business in the name of 'Mrs T P Hancock'. This new business was situated close to the shop that the plaintiff had acquired from Mr. Hancock. The new business was carried on mainly by Mr Kerr (Mr Hancocks' nephew) and Mr Hancock himself took little part. The plaintiff sued for breach of the covenant. It was held that the new business genuinely belonged and was carried on by Mrs Hancock. Mr. Hancock was not in breach of the covenant.

148 Above $\mathrm{n} 33$ [at 385]. Similar sentiments were expressed by A L Smith LJ [at 391].

149 Broderip v Salomon, above $\mathrm{n} 100$. On appeal to the House of Lords, above $\mathrm{n} 2$, it was found that Salomon had not acted mala fide, and the company was not a mere device.

150 Broderip, above $\mathrm{n} 100$ [at 339].

151 See above, text to $n$ 101. Note also Lord Halsbury's observation [at 34] that Mr Salomon was '.......not shown to have done or to have intended to do anything dishonest or untrustworthy, but to have suffered a great misfortune without any fault of his own...'

152 See the Land Registration Act 1925 s 20 . Further, Jones was not in actual occupation of the land in question, so could not have possessed an overriding interest under the Law of Property Act 1925 s.70(1)(g). Similar provisions are to be found in the Land Registration Act 2002.

153. See the argument of Lord Cooke, cited by Toulson $\mathrm{J}$ in Yukong Line Ltd $v$ Rendsberg Investments Corporation of Liberia [1998] 1 WLR 295 [at 307-308], and the observations of Burton $\mathrm{J}$ in Antonio Gramsci Shipping Corp. v Stephanovs [2011] EWHC 333 (Comm) [at 18].

154 I.e., only protected or overriding interests were capable of binding a purchaser of registered land (see the Land Registration Act 1925 s 20). See also, Williams \& Glyn's Bank v Boland [1981] AC 487. Again, the position is similar according to the regime under the Land Registration Act 2002.
} 
taken the land as mere trustee for Lipman. ${ }^{155}$ If the company had not taken the land beneficially because Lipman remained the beneficial owner even after disposing of the legal title, then the court would have been entirely justified in ordering specific performance against both trustee and beneficiary. ${ }^{156}$ This demonstrates the potential of a trust-based solution to provide more convincing reasoning than the equitable piercing doctrine.

\section{What type of trust may arise in evasion cases?}

To bring the evasion cases within the concealment principle, it must be demonstrated that they can be resolved through the imposition of a recognised type of trust of general application. If, as was suggested by the majority in Prest, the underlying reason for the court's jurisdiction to resolve veil cases stems from its more general jurisdiction to intercede in cases of fraud or unconscionability, ${ }^{157}$ then it is submitted that, as an alternative to the application of the evasion principle, the most appropriate species of trust to be imposed would be a constructive trust. ${ }^{158}$ The constructive trust is a device developed by equity for the precise function of interceding in cases of fraud or unconscionability. ${ }^{159}$ This begs the question of which recognised type of constructive trust could apply?

It is arguable that the device company could be regarded as constructive trustee for its controller on the basis that it unconscionably retained property ${ }^{160}$ that had been acquired from its controller in furtherance of the fraudulent scheme intended to frustrate the victim's pre-existing legal right, although this would extend the applicability of these trusts beyond their currently recognised ambit. ${ }^{161}$ Another option would be for the controller to retain the beneficial interest pursuant to a 'common intention' constructive trust on the ground the neither the controller nor the device company intended the device company to be the beneficial owner of the property in question. Although the deployment of 'common intention'

155 See, for example, Collings $v$ Lee [2001] 2 All ER 332.

156 Potter $v$ Sanders (1846) 6 Hare 1, is authority for the fact that when a valid contract for the sale of land is entered into, and legal title is subsequently transferred to a third party in breach of that contract, the court may (subject of course to modern land registration rules) order specific performance against both the vendor and the third party. Therefore while, as suggested by Lord Neuberger in Prest, above $\mathrm{n} 4$ [at 501]), it may not have been necessary for Russell $\mathrm{J}$ to order specific performance against the company, Russell $\mathrm{J}$ was still properly entitled to make the order against both the device company and Lipman.

157 Prest, above n 4 [at 479] per Lord Sumption, [at 503] per Lord Neuberger and [at 505] per Baroness Hale. It is interesting to observe that Baroness Hale regarded the court's power to pierce the corporate veil as being a mere manifestation of the principle pursuant to which 'the courts have power to prevent the statutes... being used as an engine of fraud'. Yet the long-standing equitable principle that a statute may not be used as an engine of fraud generally involves the court recognising a trust in order to prevent the fraud. For a discussion of this principle, see G Allan 'Once a fraud, forever a fraud: the time-honoured doctrine of parol agreement trusts' (2014) 34 LS 419.

158 Note that the conditions for the creation of an express trust by conduct, as outlined by Megarry $\mathrm{J}$ in Re Kayford [1975] 1 WLR 279 [at 282] are unlikely to be satisfied in 'evasion-type cases', and resulting trusts do not arise specifically to the purpose of preventing fraud. It is arguable, however, that Jones, above $\mathrm{n} 18$, may have been resolved by the simple imposition of a resulting trust on the basis that there was insufficient evidence that the parties intended to transfer the beneficial interest. This conclusion may be sustained on the basis that the consideration provided by the company was most likely illusory, at least for the purposes of establishing a resulting trust, see, for example, Birch $v$ Blagrave (1755) Amb 264; Platamone v Staple (1815) G Coo 250; Davies v Otty (No 2) (1865) 35 Beav 208; Kuppusami v Kuppusami [2002] EWHC 2578 (Ch); Ali v Khan [2002] EWCA Civ 974; [2002] WTLR 187. In all of these said cases, the court recognised a resulting trust in favour of the transferor on the ground that there was insufficient evidence that the parties intended to transfer the beneficial interest.

159 See, for example, Paragon, above n 127 [at 409] per Millett LJ.

160 This could include assets, rights or a business.

161 See above, text to n 115. 
constructive trusts by this means may prove controversial, there is, as previously observed, authority for the proposition that 'common intention' constructive trusts, which are founded to prevent unconscionable conduct, ${ }^{162}$ may be raised between 'one-man type companies' and their controllers. ${ }^{163}$

Although the raising of a recognised species of constructive trust based upon the unconscionable behaviour of a device company would offer a logical theoretical foundation to support the use of the concealment principle in evasion type cases, a practical and obvious disadvantage of this constructive trust argument would be that it could be applied to cases outside the strict confines of the evasion principle. Here the floodgates could be opened to arguments around circumventing corporate personality on the premise of a justice-based argument in circumstances where a company was incorporated or subsequently used by its controller to exert an unfair advantage of an unconscionable nature. ${ }^{164}$ While this disadvantage may in fact have the advantage of curbing the exploitation of the corporate form to an objective previously advocated by Lord Denning, ${ }^{165}$ and, furthermore, could open up the possibility of being applied to cases involving groups of companies, it would clearly fall foul of the judicial stance which has developed postAdams. ${ }^{166}$ Accordingly, if a species of constructive trust based upon the unconscionable behaviour of a device company is to be advanced as an alternative to the evasion principle, the factual circumstances justifying an ability to invoke the constructive trust must be constrained. This could be achieved if it is recognised that the constituent elements of the evasion principle give rise to a distinctive and exclusive type of constructive trust which arises only in circumstances that would otherwise justify the operation of the evasion principle, namely in circumstances where a device company was incorporated by its controller to avoid an existing obligation of the controller. ${ }^{167}$

It is contended that the implied use of this form of constructive trust device ('the evasion trust') may be found in the recent and post-Prest decision of JSC BTA Bank $v$ Solodchenko. ${ }^{168}$ Here the defendant purchased certain properties in the name of companies under his control in order evade a claim by the claimant, who eventually obtained judgment and a freezing order against the defendant. The claimant successfully claimed, on the basis

162 See, for example, Gissing v Gissing [1971] AC 886 and Lloyd's Bank v Rosset [1991] AC 107. Although unconscionability was not mentioned in the recent cases of Stack $v$ Dowden [2007] UKHL 17; [2007] 2 AC 432 and Jones v Kernott [2011] UKSC 53; [2012] 1 AC 776, neither of these latter two cases was directly concerned with cases involving a single legal owner of the disputed property. $163 \mathrm{M} v \mathrm{M}$, above $\mathrm{n} 116$.

164 For example, a constructive trust based on unconscionable retention or a 'common intention' constructive trust could, if extended to cases such as Gilford, could also potentially apply to cases such as Ord, above n 142.

${ }^{165} \mathrm{~A}$ justice criterion for piercing the corporate veil was accepted by Lord Denning in, for example, Littlewoods Mail Order Stores Ltd v IRC [1969] 1 WLR 1241 and Wallensteiner v Moir [1974] 1 WLR 991. Lord Denning considered that the judiciary had a discretion to pierce the corporate veil in circumstances where justice demanded that the corporate personality of a company should be ignored.

166 Discussed above, text to $\mathrm{n} 82$.

167 It is to be observed that the 'evasion trust' would not be a constructive trust of general application, and as such, would technically fall outside a strict interpretation of the concealment principle. It is, however, not unusual for the courts to develop strict pre-requisites for the invocation of specific trustbased doctrines which are founded, in general terms, on the prevention of fraud or unconscionability. Obvious examples include the 'Pallant $v$ Morgan equity' (see Banner Homes $v$ Luff Developments [2000] Ch 372), the doctrine of secret trusts (see Blackwell v Blackwell [1929] AC 318), and the doctrine of proprietary estoppel (see Thorner v Major [2009] UKHL 18; [2009] 1 WLR 776). 168 [2015] EWHC 3680 (Comm). 
of the evasion principle, that the defendant was the beneficial owner of the properties. ${ }^{169}$ The court's declaration dealt only with beneficial ownership; legal title to the properties was retained by the device companies. It is suggested that this judgment implies that the constituent elements of the evasion principle may be capable of being applied to generate a trust relationship. Another recent case, Wood v Baker, ${ }^{170}$ may support this construction. ${ }^{171}$ Here, a bankrupt diverted funds to accounts in the names of device companies in order to evade his statutory obligations to disclose and forfeit after-acquired assets. ${ }^{172}$ It was held that the evasion principle was capable of justifying ${ }^{173}$ a ruling that the bankrupt 'own[ed] and control[ed] ${ }^{174}$ the funds in question, notwithstanding that legal title was held by the device companies.

A recognition that the evasion principle may be effectuated through use of a trust device may provide some doctrinal guidance for future courts when refining the strict prerequisites laid down in Prest for invocation of the evasion principle. For example, Prest did not really address the question of how inevitable a liability must be for the evasion thereof to trigger the evasion principle. ${ }^{175}$ Further, the multitude of cases and academic literature concerning the recognition of trusts for the prevention of unconscionable conduct ${ }^{176}$ may serve, for example, to embolden the courts to feel justified in adopting an extended interpretation of the requirement that the 'evaded obligation' must have been 'pre-existing'.

Indeed, it is suggested that, in the future development of the law, the 'evasion trust' could be extended in a manner which is consistent with the judgments in Salomon yet disparate from the advancement of any argument that would promote the view that corporate personality should be disturbed on the basis of a 'pure justice approach.' The extension would seek simply to prevent any fraudulent and intentional abuse of the incorporation process. While the evasion principle is an example of an intentional and fraudulent abuse of the incorporation process, it is not the only example of this species of fraud. A fraudulent and intentional abuse of the incorporation process may occur in any situation where, in incorporating a company, its controller's intention was to perpetrate a fraudulent deception by the newly incorporated company to the controller's commercial advantage and to the

169 Phillips $\mathrm{J}$ held [at 8-9] that the companies were resulting trustees for the defendant or that, if a resulting trust could not be established, the claimant was beneficial owner on the basis of the evasion principle.

170 [2015] EWHC 2536 (Ch).

171 The 'evasion trust' may simply be the label which most accurately describes the consequences of invocation of the evasion principle. In both JSC and Wood it was held that application of the evasion principle did enable the court to recognise the beneficial ownership of assets as separate from the legal title as an alternative to recognising a trust arising for conventional reasons.

172 See Insolvency Act 1986, ss 333 and 307.

173 The case concerned an application for an interim freezing order against, inter alia, the assets and businesses of the device companies. It was thus only necessary for the applicant (the trustee in bankruptcy) to prove a 'good arguable case' ([at 34] per Hodge QC sitting as Judge of the High Court). The court held [at 32] per Hodge QC that the evasion principle provided 'the most compelling justification' .

${ }_{174}$ Although the nebulous phrase 'agents and nominees' ([at 32] per Hodge QC) was again used to describe the capacity in which the companies held the assets, it is evident that the court had in mind a trust relationship, for the companies were described [at 32] as 'holding the assets on his behalf'. Hodge QC also preferred an explanation based on the evasion principle over counsel's arguments that the companies were agents or trustees in a more conventional sense (see [30], [32] and [33]. $175 \mathrm{~A}$ detailed pre-Prest treatment of this vexed and important question can be found in Raja $v$ Van Hoogstraten [2006] EWHC 2564 (Ch) [at 31] per Pumfrey J.

176 See, for example, B McFarlane 'Constructive trusts arising on a receipt of property sub conditione' (2004) LQR 667; S Gardner, 'Reliance-based constructive trusts', in C Mitchell (ed), Constructive and Resulting Trusts (Oxford: Hart, 2009); N Hopkins, 'Conscience, Discretion and the Creation of Property Rights' (2006) 26 LS 475; G Allan above n 157. 
detriment of an innocent third party. It is suggested that such an extension to the 'evasion trust' would explain the judicially accepted piercing cases that exhibit the hallmarks of an intentional fraud but which nevertheless fall outside the strict technical requirements of the evasion principle. ${ }^{177}$ The extension would also, in part, concur with the majority view advanced in Prest, ${ }^{178}$ namely that, in future cases, factual circumstances falling outside the ambit of the existing evasion principle may still justify a disturbance of the corporate veil. As a matter of promoting clarity in the law, how can it be considered logical to disturb corporate personality in circumstances where the strict technical requirements of the evasion principle are met but not in other types of cases exhibiting an obvious example of an intentional and fraudulent abuse of the incorporation process? ${ }^{179}$

\section{CONCLUSION}

In Prest, the Supreme Court's justifications for the disturbance of corporate personality resulted in a majority opinion which favoured the circumvention of corporate personality by applying established legal principles (the concealment principle). This article supports the approach advanced by the Supreme Court, although it is contended that, other than in cases involving groups of companies, the concealment principle should be invoked by applying principles of trust law as opposed to principles of agency law. In practice, the agency-based solution is unworkable and confused in its application to 'one-man type companies' and runs contrary to the seminal authority of Salomon. Additionally, in the Trustor-Gencor line of 'piercing-type cases', the agency-based solution would appear, as a matter of legal principle, to preclude the finding of any in personam equitable liability against the device company. In the provision of a doctrinally sound framework to support the development of the concealment principle in the post-Prest era, this article asserts that the application of ordinary rules relating to trust law advances greater clarity and certainty than the rules of agency.

This article identifies two distinct trust law-based solutions to justify the use of the concealment principle for resolving cases in which 'piercing issues' may arise. These two distinct trust law solutions, 'the trust solution' and 'the accessory solution', fall within the spirit of the majority decision in Prest, in that they provide a means of circumventing the corporate veil through the use of ordinary legal principles without recourse to veil-piercing. In relation to the Trustor-Gencor line of cases, it is contended that the joint and several liability of the company and its controller is best explained through the application of the accessory solution. While the accessory solution depends upon the feasibility of 'double counting' the directing mind of the controller of the device company to establish the liability of both, such 'double counting' of a directing mind is not without precedent in circumstances where, as in the application of the accessory solution, the liability of both the company and its controller is

177 Existing examples of such a case would include Re Darby; Ex p Brougham [1911] 1 KB 95; Drew v. HM Advocate 1995 SCCR 647; 1996 SLT.1062 and Kensington International Limited v. Republic of Congo \& Ors [2005] EWHC 2684 (Comm); [2006] 2 BCLC 296.

178 See above $\mathrm{n} 4$.

179 See further and by analogy, S. Griffin 'Disturbing Corporate Personality to Remedy a Fraudulent Incorporation - An Analysis of the Piercing Principle' (2015) 66 NILQ 321. The substance of this article contends that as an alternative to disturbing corporate personality by applying the concealment principle, it may be possible, in following the true spirit of the judgments advanced by the House of Lords in Salomon, to extend the current and accepted equitable piercing principle (the evasion principle) to cases exhibiting an intentional and fraudulent abuse of the incorporation process. 
derived and defined as a consequence of their distinct responsibilities. This solution also affords a relative stringency in the requirement to establish the dishonesty of the controller. Overall, it is submitted the accessory solution provides a means by which the law can be developed in a manner consistent with judicial and theoretical requirements for doctrinal clarity. Accordingly, it is asserted that, in future, the accessory solution should be utilised to resolve concealment cases that fall within the Trustor-Gencor line of authorities.

In contrast to the cases in the Trustor-Gencor line, cases falling within the evasion principle do not involve the transfer of an asset in breach of a fiduciary duty and therefore cannot be resolved by applying the accessory solution. These 'evasion cases' may, however, be amenable to a form of trust solution. By applying attribution principles, a conventional species of constructive trust may arise between the device company and its controller. Accordingly, the controller may be liable, in the eye of equity, for any improprieties that were ostensibly committed by the device company. It is submitted that the trust solution provides a plausible theoretical basis for resolving cases that would otherwise turn upon the invocation of the evasion principle.

This article recognises, however, the danger that if the trust solution was to be applied without some form of formal restraint, the practical consequences arising therefrom could be revolutionary in limiting the protection afforded currently to the sanctity of the Salomon principle. Given the probable abhorrence of the commercial world to such a revolution, it is accepted that an ability to apply the trust solution to the 'evasion cases' would need to be on the premise that the successful invocation of the evasion principle would raise a distinct species of constructive trust. Indeed, it is suggested that the post-Prest law may be developing along these lines. Whilst not altering the substance of the law, such a development provides doctrinal clarity to the mechanism of equity which facilitates the disturbance of the corporate veil in circumstances when the evasion principle is invoked.

This article further recognises, however, that the restrictive scope and limited application of the constituent elements of the evasion principle may not always have sufficient aptitude to curtail a fraudulent and intentional manipulation of the incorporation process. To this end, this article promotes an extension to the otherwise suggested 'evasion trust' species of constructive trust, whereby this constructive trust device could be applied to all cases exhibiting the obvious hallmarks of an intentional and fraudulent abuse of the incorporation process. This extension would result in the complete abrogation of the equitable piercing doctrine. Although such a suggestion may appear radical, it is one which would actually promote clarity and certainty in the law without evoking the "commercial law revolution' associated with then adoption of a justice-based argument. This extension would also provide a rational explanation for the previously decided 'piercing cases' which fall outside of the evasion principle but which nevertheless exhibit an intentional and fraudulent abuse of the incorporation process. 